\title{
Book Recommendation
}

\author{
Victor Merriman's Austerity and the Public \\ Role of Drama: Performing Lives-in-Common
}

Jazmin Badong Llana

De La Salle University, Manila

\section{Abstract}

What role does drama play in a society that is so thoroughly structured and governed by the logics of neoliberalism that even people who suffer the effects of Deficit Culture and the doctrine of Austerity cannot see through the dominant rhetoric and ideology? The author and dramatist Victor Merriman critically identifies the erosion of public discourse and politics as a key reason and places drama in the important role of reinstating the public and rebuilding democracy. My review of the book takes a transnational perspective, acknowledging my own positionality coming from the Global South in relation to the author's own context as a British scholar and artist in the Global North writing mainly on the British experience, but attentive to the book's exposition on and about drama as public art in the generic and universal sense.

\section{Keywords}

drama, theatre, performance, public, counterpublic, public art, limits of liberalism, democracy 
Contrary to the view that neoliberalism embodies the democratic ideals, the book Austerity and the Public Role of Drama:Performing Lives-in-Common argues that democracy and the public discourse that manifests and supports democracy have been steadily eroded in the neoliberal social order. The discourse of Austerity and the rhetoric of Deficit Culture have come to dominate all aspects of life to such an extent that even people who suffer their dire effects have come to accept that "there is no alternative". The idea of the public, so crucial to democracy, has lost to the logics of an ideology that blames the ills of society on its victims, who are thereby rendered unable to speak up and assert themselves. This is the context in which Victor Merriman locates the important role of drama in reinstating the public and rebuilding democracy.

In eight chapters progressively organized one after another to lay down premises and build a case for the book, Victor Merriman convincingly argues for the role of drama as public art in light of the disappearance of public discourse and its consequent displacement of politics in what he calls "Deficit Culture" and the banner call for Austerity under the neo-liberal political economic order. The book has two parts: Part I, titled “Neo-liberalism's Political and Moral Economic Project: The End of Public Life?” and Part II, "Performance, the Academy, and the Politics of Austerity", which ends with the essay "Beyond Repair: A Critical Performance Manifesto”.

Part I begins with “Austerity and Drama's Public Role”, which serves as an introduction to the book, describing what it intends to do and how the discussion is laid out, and, as an elaboration of the context within which the book emerged and for which it is written as a response. What follow are two chapters: Chapter 2, "The Public World: An Idea Under Pressure" and Chapter 3, "Drama in Public Worlds." The second chapter parses the literature on "the idea of a public" as being the crucial underpinning of liberal culture from the late eighteenth century and on the threats to liberalism itself by its erosion in recent history (Austerity 13). Such a review reveals a "liberal spectrum" from classical liberalism to neo-liberalism and a "bifurcated" post-liberalism that has radical and conservative forms (15). What is evident across this spectrum is the "mutation" of the public as liberal idea in its origins and as "[foundation of] both a political economy and a social 
contract", how this has been "degraded" but "not destroyed" by neo-liberalisation's telling of "a new human story" (13) that justifies the call to austerity and shapes how individual citizens of liberal democracies see themselves and their lives and what they should strive for-as homo economicus and not/ anymore as homo politicus. This new human story is hegemonic and invokes religion for efficacy, casting it in the language of a morality play where the sin is named, the sinner identified (inevitably the individual citizen who lives beyond his means or depends on social welfare), and the penance given: austerity. "Deficit Culture" is therefore also pedagogy deployed as social drama, "with recognizably dramatic features: character, personality, belief, moral conflict, and heroic vision" (16). In Chapter 3, the point of the erosion of ideas of the public under neo-liberalism is carried forward with a discussion of how "[public acts have been displaced] by performative acts in the neo-liberalisation of everyday life" and deployment of the trope, "There Is No Alternative (TINA)' in contemporary critical communication as performance" (7).

Part II has the remaining five chapters: Chapter 4, "Drama Worlds as Public Worlds"; Chapter 5, "Confronting Corporate Neo-liberalism in Jim Nolan's Johnny I Hardly Knew Ye (2016)”; Chapter 6, "(Re)Public Worlds: Drama as Ethical Encounter"; Chapter 7, "Beyond Deficit: Conceptualising Collectives"; and Chapter 8, "Beyond Repair: A Critical Performance Manifesto." These chapters further build on the argument set out in the first three by means of performance analyses of Dario Fo's Francis: The Holy Jester (2009) from Italy; the corpus of activist performances by Reverend Billy Talen and the Church of Stop Shopping Choir from the United States of America; Jim Nolan's Johnny I Hardly Knew Ye (2016) from Ireland; and three works of the author's own company, the One Hour Theatre Company at Edge Hill University: Half Measures (2016), Lear in Brexitland (2017), and A Pound of Flesh (2017). In addition, in Chapter 8, there is a discussion of the Guardian Brexit Shorts (2017).

These works demonstrate how artists are speaking to and against the dominant narrative of TINA ("There Is No Alternative") and making possible the involvement and action of audiences who otherwise would go about 
their lives as they would in the order established by the "governmentality" of neoliberalism. In all of these, the message is clear: drama is a public art form that can and should instantiate the creation of a public that can engage in difficult public discourse and in so doing embody democratic ideas/ideals. As Merriman says, "... [T] he importance of ideas of the public in shaping lived experiences of democracy cannot be overstated" (Austerity 6), since democracy is not just an idea but a real experience of being heard, enjoying freedoms-according to political scientist Paul Hutchcroft, "true democracy" is a system that enables the actual enjoyment of individual freedoms by citizens, including freedom from hunger and freedom of creative expression-in short, the kind of human flourishing Merriman talks about in the book. For Merriman, the ideas of a public and its very existence "shape" the experience of democracy, that is to say, publicness or the existence of a public sphere and public discourse is a necessary condition for and embodiment of democracy. People's participation in a/the public is conditioned by understandings of publicness or being in public, but these are the very ones threatened under neoliberalism: "What is at stake . . is not only the existence of socio-political practices by means of which a public sphere, public realm, public man or woman, or public intellectual has been constituted, sustained, and evolved, but the very capacity to imagine them" (citing Wendy Brown 2015, Austerity 6). Drama has the capacity to do so and actually makes this happen. And Merriman does not only declare this but puts forward a Manifesto of how it can be done, with a matrix of problems and solutions for action in the last chapter.

The tone is urgent and passionate. But what makes the book engaging is a style of writing that deploys rhetorical devices that one may find in dramatic texts of satire and black comedy, perhaps speaking of the author's background as a dramatist himself, helped along by generous excerpts from the performances referenced and analyzed. There are parts that are almost hilarious, except that my amusement/bemusement stemmed mainly from an ignorant outsider perspective, as when Merriman talks about UK plc as a long running, crisis-driven soap opera that "chronicles the vicissitudes of its central couple, TINA (There Is No Alternative) and the Taxpayer" (16)- 
almost hilarious if not for the fact that "even government publications and trade campaigns refer without irony to an entity called UK plc" (49), which the Internet defines as "The commercial organizations or interests of Britain or the UK considered collectively; the British or UK economy" (Lexico).

The discursive review of literature, referencing relevant key texts on liberalism, neo-liberalisation, and post-liberalism, like those of Lloyd and Thomas (1998), Klein (2007), Goodhart (2014), Pettit (2014), Brown (2015), Milbank and Pabst (2016), McFalls and Pandolfi (2012), Alexander (2011), and Wainwright (2018), among others, makes the book a good resource for further reading. In addition, there is a plethora of references to interviews and statements (mainly from The Guardian) made by key personalities from Margaret Thatcher to David Cameron, that provides documentary evidence for what is argued as a descent from social democracy to neo-liberalism and the consequent abandonment by the state of the citizens now cast as "degraded denizens" (68), with the white working class people becoming increasingly xenophobic and racist and the immigrants getting further pushed to the margins of British society. The analyses of the plays that make up most of the book provide compelling support and work not only as illustrations but as a fleshing out of the main ideas. Moreover, what makes the book invaluable as reference and resource material is the way the chapters begin with an abstract and end with a summary, which aid the reader in following the premises and argument, and how the Manifesto of the last chapter concludes the book. Merriman goes beyond polemics and provides a way forward-as he says it in the conclusion, an alternative to "serfdom" (168).

What made the reading initially difficult for me was the very British context. I am not saying this is a flaw of the book, only that a non-British reader should be alerted to this point early on, perhaps in the introduction. There was a sense sometimes that I was peeping into a room where the people conversing knew the topic of conversation but I did not, since I am from a different place. But this is also the reason I am/was able to tune in to the conversation. I am from/with the Global South, who represent the reciprocals of what are experienced now in the Global North under Deficit Culture-"those who have suffered in a systematic way because of 
the injustices, dominations, and oppressions of colonialism, capitalism, and patriarchy" (quoting Santos 159). I am of "the Third World" spoken about as beset by "oppressive . . conditions now distributed globally, across all countries" (137) and the site/s of "epistimicide" that was the consequence of

Liberalism's colonial adventures . . . the destruction of the knowledge of subjugated populations and their cultures, memories, ancestries, and all the ways they relate to each other and to nature ... [with] their legal forms, political forms, organization-everything-[destroyed] and put at the service of the colonial occupation (159).

But, also, I am of the Global South that Merriman cites as the source of many practices of drama as public art, practices of resistance to the continuing depredations of the cultures and lives of people who oftentimes figure in the colonial imaginary-"the brutal colonialist practices of differentiation" as "subhuman" (159).

It can be asked why I chose to review this book with its very British context. There is a background story here, which provides a practical explanation. I was asked to respond to a keynote talk by the author who spoke mostly of what he propounds in this book, and writing the review essay was just a step further. Having said that, however, I insist that the book offers a challenge to thinking through the idea of drama as public art in a transnational context, in a way that rejects or disavows what the philosopher Alain Badiou calls the "predicates" of place and identity. The response to the book from a transnational perspective would inquire into the public role of drama in its "universal" sense, and by this I also refer to Badiou's notion of the universal-truth-as being so because of its address: it is addressed to all, in this case, whether British or Filipino or a totally different nationality: "Truth is diagonal relative to every communitarian subset; it neither claims authority from, nor constitutes, any identity. It is offered to all, or addressed to everyone, without a condition of belonging being able to limit this offer or this address" (Saint Paul 14). The overarching argument of the book is an assertion of drama's public role sui generis, one that any reader of any nationality is invited or challenged to receive as such, even if 
the author scaffolds his assertion with material experiences mainly from his local context and especially from his own work with the One Hour Theatre Company (OHTC). And Merriman does bring in other/non-British experiences, with the excellent examples from Ireland, Italy, and the United States, as well as a mention of works from "the Global South", including the Philippines. Importantly, Merriman cites Badiou when speaking of "identitarianism", which forms an "ideal [that] represents the most primitive, the most fundamental product of state repression" (quoting Badiou 2012, 36), as when citizens are called to conform to notions of Englishness (or, in our case, Filipinoness?). I read this as a movement precisely away from the particularity of British experience and towards a "horizontal" connection with other experiences in order to affirm a commitment to a generic sense of drama as public art. As Badiou declares, "[T] he central dialectic at work in the universal is that of the local, as subject, and the global, as infinite procedure" ("Eight Theses" 2006). Merriman keeps to this "infinite procedure" with his declarations on the public role of drama, which the reader would interpret as possibly including his/her own experience of drama/ theater, and those of infinite others, especially and possibly because they, too, could have been struck by the same "lightning bolt" of Theatre with a capital "T". As Merriman quotes from Badiou's "Rhapsody of the Theatre": "Theatre[:] a heresy in action [that] detaches itself from 'theatre' as a rather implausible lightning bolt (190)" . . . where the "'Spectator' . . . is a witness,

with real, though latent, capacity to act, should lightning strike" (Austerity 142). It is important to note here that Merriman invests the term "Drama" with special significance, using it throughout the book with a capital "D", not as a matter of style perhaps but after Badiou's "Theater" with a capital "T". It is also clear that while Merriman uses "Drama", he means more than merely the text or dramatic script that is usually denoted by the term as opposed to "theatre" which is conventionally used to refer to performance. And so the public role of Drama is also really the public role of Theatre as performance. He signals this in the introduction: “. . . Drama-or Performance, conceived more broadly" (Austerity 3) and in the manifesto on "Drama's potential as critical performance of lives-in-common" (9). 
The book initiates a discourse on Drama as public art that draws us, the readers, in, and therefore performatively enacts the creation of a public. I am thinking of Michael Warner's famous book Publics and Counterpublics (2005) where Warner defines "public" as "the social space created by the reflexive circulation of discourse" (90), elaborated as "a space of discourse organized by discourse" (68) and as a relationship among strangers (74), its requirement for membership being an "active uptake" in the minimal form of attention (87). As Warner points out at the beginning of his book, I became part of the public of his book because I read it. In a similar way, I have become a part of the public of Merriman's book by virtue of having read it-which is to say that Merriman is performing a double act: firstly, initiating a discourse on drama as public art with his book and, secondly, "performing public" with his own work as dramatist in the OHTC and amplifying this along with the work in public by the other artists and works he features in the book. I use here "performing public" with a nod to an issue of the journal Performance Research, "Performing Publics", the theme of the annual conference of Performance Studies international (PSi) in 2011, with many of the contributions drawn or developed from papers presented in the conference, as well as to an essay by Gigi Argyropoulou also titled "Performing Publics" in a later volume (Argyropoulou 214-218). The 2011 conference and journal issue were "[responses] to Michael Warner's important question about the disciplinary stakes of thinking public" (Levin and Schweitzer 2); the essay by Argyropoulou published seven years later revisits the questions posed in the 2011 issue.

Merriman does not cite Warner at all. I surmise he might not have found Warner's notion of the public useful for his own critical work, bearing in mind that Warner says that "public" is not or is different from "audience" (Warner 71), although he identifies "theatrical public" as the second "sense" of "a public" (66). Neither is there a reference to Nancy Fraser's important essay on "subaltern counterpublics" and performances of protest by the "members of subordinated social groups-women, workers, peoples of color, and gays and lesbians" (Fraser 67). Part of my joining this space of discourse on drama as public art instantiated by Merriman's book is a conversation 
between Warner's notion of publics and counterpublics and Fraser's naming and critical discussion of subaltern counterpublics. I have a contribution in the 2011 issue cited above, where I talk about a post-colonial counterpublic (Llana 91-96).

It would be interesting to read Merriman's notion of public art against what Warner sets out as the disciplinary criteria of being public, which, however, is a subject beyond the scope of this essay. It is sufficient to say here that I find strong resonances of the notion of counterpublics in the work that drama as public art does as expounded by Merriman. To cite just one connection: both are affective sites of the reflexive circulation of discourse, marshalling the "poetic-expressive" as opposed to the "rational-critical" language and performance of the dominant public, that is to say, the public that comes under "the superintending power of the state" (Warner 116).

In his book, Merriman speaks unequivocally with people living at the fringes and underside of society (subalterns) in the Global North, which in his telling has now much in common with the Global South. Like colonized populations, the "denizens" of the neoliberal First World are mired in poverty, debt, unemployment, lack of opportunity (like the character Lee Smith in OHTC's 2017 Lear in Brexitland who says he waited for ten years to get a job, only to be robbed of it and languish in the hospital that is the setting of the play's action [see Austerity 108-114]) and epistemologically gripped in the fantasy and view of the world and themselves woven by Deficit Culture. This has come about because the "limits of liberal democratic culture and institutions as guarantors of freedom and justice have become all too apparent" ("Scholarship and Human Flourishing" 2019) in the wake of the global financial crisis of 2007-2008, but the Austerity discourse had been there a long time ago with the institution of neoliberalism as political economy.

In such a context, "Drama" as public art has to go beyond its moorings in liberal thought and fully become a plural relation, an act of two (see the reference to Brecht: "the smallest social unit is not one person, but two people-a view repugnant to Deficit Culture”, Austerity 160). Merriman's call to exceed the limits of liberalism reminds us that liberalism in its classical 
foundations was intended in the first place "for the free" and occluded those who were not free: the women, the slaves, the foreigners. As Merriman shows, the limits of liberalism and liberal democracy are embedded deep in its DNA. Exceeding such limits entails the difficult and painful labor of untangling ourselves from the epistemological bind of liberalism's idea of the "universality of the human subject" in order to enable and thus constitute, through our work, the appearance of the true Subject. Following Merriman's prompt, I take this Subject to be the Human in the generic sense present in all of us but hidden or suppressed by conditions like those imposed by Deficit Culture.

Merriman does not say that all drama/theatre fulfils emancipatory work as public art. It is in fact thoroughly embedded and governed by the logic of neoliberalism. There is much to learn from the reflections in the book on the complicity of academia/the university and other cultural and art institutions (theaters and theater organizations included), on the self-styling by artists and intellectuals as "creatives" within the frames of "creative' or 'cultural' industries" under the banner of neoliberalism (Austerity 152), and the practice of claiming to be "socially conscious but not politically engaged" that Merriman deplores ("Scholarship and Human Flourishing” 2019). The book offers a strong cautionary comment on such complicity.

Drama is a critical ethical practice, an engagement from the bottom up-from the ground, on the ground, immersed in the ways of thinking and practices of "subjugated populations" (Austerity 159) or the "practical knowledge of working or would-be working people" (137) , or indigenous ways also known by many cultural workers in the Philippines as IKSP: indigenous knowledge, systems, and practices-which is also to say that this practice of thinking and making contributes to the building of true democracy. In the Manifesto, Merriman avers that democracy-building needs committed critical scholarship across disciplines, one that "feeds democratic discourse and institutions by enfranchising those currently excluded" (166). Filipino readers would find much resonance here: such an ethical act contributing to democracy-building is something we gravely need now in the Philippines under President Duterte not only in terms of what we can do and in vigor- 
ously resisting our own brand of "TINA"-the "There Is No Alternative" discourse-but also in the investigation of our changing material conditions, including the effects of the contemporary colonization: neoliberalism.

"We can't do this alone"; there is a need for building "collective strategic intelligence" (136, 143-4, 155) and "horizontal relationships" (52, 167). These calls to action both drawn by Merriman from the work of Hilary Wainwright (44-52) are important insights and prompts for the reader, myself included.

Let me end with the thought that there should be a sequel to this book but one set in the time of the coronavirus pandemic, lockouts, and consequent overturning of everything in our contemporary life, in Britain and elsewhere, everywhere in the world. After actual public gatherings were prohibited or could not happen. After many of the "denizens" were infected and died. After the Brexit trade deal was finalized, four years after the historic vote to leave the European Union, in the midst of the pandemic crisis. After the theaters were forced to close and physical, on-site and live gatherings could not happen, and the subsequent recourse to online forms of interaction and making work that insists it is still theater. In such a sequel, the question might be: in this living dystopia, how can drama continue its role as public art? 


\section{Works Cited}

Argyropoulou, Gigi. "Performing Publics." Performance Research, vol. 23, no. 4-5, 2018, pp. 214-218, doi:10.1080/13528165.2018.1507352.

Badiou, Alain. "Eight Theses on the Universal." 2006, www.lacan.com/badeight. htm.

---. The Rebirth of History: Times of Riots and Uprisings. Verso, 2012.

---. "Rhapsody for the Theatre: A Short Philosophical Treatise." Theatre Survey, vol. 49, no. 2, 2008, pp. 187-238.

---. Saint Paul: The Foundation of Universalism. Translated by Ray Brassier, Stanford UP, 2003.

Brown, Wendy. Undoing the Demos: Neoliberalism's Stealth Revolution. Zone Books, 2015.

Fraser, Nancy. "Rethinking the Public Sphere: A Contribution to the Critique of Actually Existing Democracy." Habermas and the Public Sphere, edited by Craig Calhoun, The MIT Press, 1992, pp. 109-142.

Hutchcroft, Paul. "Forum on Challenges to Liberal Democracy." De La Salle University, 2019.

Levin, Laura and Marlis Schweitzer. "Editorial Performing Publics.” Performance Research, vol. 16, no. 2, 2011, pp. 1-6, doi:10.1080/13528165.2011.578712.

Lexico, Oxford English Dictionary. “Uk Plc.” www.lexico.com/definition/uk_plc-. Accessed 15 Mar. 2021.

Llana, Jazmin Badong. "Pilgrimage as Utopian Performative for a Post-Colonial Counterpublic.” Performance Research, vol. 16, no. 2, 2011, pp. 91-96, dx.doi. org/10.1080/13528165.2011.578839.

Merriman, Victor. Austerity and the Public Role of Drama: Performing Lives-inCommon. Palgrave Macmillan Pivot, 2019.

---. "Scholarship and Human Flourishing: A Manifesto for Critique as Ethical Public Action." International Conference on Ethical Literary Criticism and Interdisciplinary Studies, University of Santo Tomas, 2019.

Santos, Boaventura de Sousa. Conversations in Postcolonial Thought, edited by Katy P. Sian, Palgrave Macmillan, 2014, pp. 63-80.

Wainwright, Hilary. New Politics from the Left. Polity Press, 2018.

Warner, Michael. Publics and Counterpublics. Zone Books, 2005. 